\title{
Assistance to people with mental disabilities: a discussion from the social integration
}

Tahyná Duda de Almeida ${ }^{a}$, Paula Mendes Santos ${ }^{a}$, Gabriela Lopes Angelob, Suélen Alves Teixeira ${ }^{a}$, Ana Cristina Oliveira ${ }^{a}$

\begin{abstract}
Objective: While the process of social inclusion have promoted respect for the person with menta disability, the stigma against this individual is still very present in society, so that individual identified from their difference, now identified as being a weak, fragile and sometimes abnormal and identified as someone with a determination that can break barriers, even the difference. Considering that the social integration of individuals with disabilities still means a great challenge for society, this study sought to discuss issues related to targeted assistance to the population with mental disabilities within this integration process. The way society perceives and relates to people with disabilities is a repetition of the speech and behavior of its own professionals and programs involved in social integration and rehabilitation of these individuals.

Conclusion: The educational institutions of human resources, and assistance programs aimed at the disabled, need to promote reflections on the densest kind of discourse and practices used in everyday life of these people and their families. They should not act based on prejudice.
\end{abstract}

Key words: Disabled persons. Mental retardation. Public assistance. Social services. Health services accessibility.

\section{Assistência direcionada às pessoas com deficiência mental: uma discussão a partir da integração social}

\section{RESUMO}

Objetivo: Apesar do processo de inclusão social ter promovido o respeito à pessoa com deficiência mental, o estigma perante esse indivíduo ainda está muito presente na sociedade, sendo esse indivíduo identificado a partir da sua diferença, ora identificado como um ser debilitado, frágil e anormal e ora identificado como alguém portador de uma determinação capaz de romper barreiras, até mesmo a barreira da diferença. Considerando-se que a integração social dos indivíduos com deficiência ainda significa um grande desafio para a sociedade, este estudo buscou discutir questões relacionadas à assistência direcionada à população portadora de deficiência mental dentro deste processo integrador. A forma como a sociedade percebe e se relaciona com portadores de deficiência é uma repetição do discurso e do comportamento dos próprios profissionais e programas envolvidos na integração social e reabilitação desses indivíduos.

Conclusão: As instituições formadoras de recursos humanos, bem como os programas de assistência voltados para o portador de deficiência, necessitam promover reflexões mais densas quanto ao tipo de discurso e práticas utilizados no dia a dia destas pessoas e familiares. Não devem atuar com base em preconceitos.

Palavras-chaves: Pessoas portadoras de deficiência. Retardo mental. Assistência pública. Serviços de assistência social. Acesso aos serviços de saúde.
${ }^{\text {a }}$ Postgraduate Program in Dentistry, Federal University of Minas Gerais, Belo Horizonte, MG Brazil,

${ }^{b}$ Faculty of Dentistry, Federal University of Minas Gerais, Belo Horizonte, MG, Brazil, 


\section{INTRODUCTION}

The disability is the subject of study in different fields of knowledge and the disabled, the target of public and private social action. The deficiencies usually are measured in degrees and qualified by statistical measures (intelligence, vision, hearing, movement, behavior) and social and pragmatic measures (taken from the population mean according to social expectations and cultural values. These criteria are arbitrary and vary from culture to culture [1].

According to the Decree number 3.298, of December 20, 1999 (available on the National Policy for the Integration of Persons with Disabilities), in the Article $4^{\circ}$ defined as a person with mental disability the individual who has an "intellectual functioning significantly below average, manifesting before the age of eighteen and limitations associated with two or more adaptive skill areas such as: a) communication, b) personal care; c) social skills, d) use of community e) health and safety; f) academic skills; g) leisure; h) work" [2]. Undoubtedly, the emergence of a discourse that supports social inclusion appreciated the point of view of respect for persons with mental disabilities in their differences. In this sense, the prevailing idea of securing rights of citizenship, enabling opportunities for the poor to self-organize and build psychological resources, social and cultural rights to share more fully in social life [3].

Considering that the social integration of individuals with disabilities still means a great challenge for society, this study sought to discuss issues related to assistance and care dedicated to people with mental disabilities within this integration process.

\section{SOCIAL INTEGRATION}

\section{The family of the individual with mental retardation}

The family is the most densely social "disturbed" by the birth of an "abnormal" child. The severity of the fear of "disease" of the child and the recognition that it may need special services demonstrates the anguish of parents facing the new reality [4-9]. There is often a psychological trauma of the family, which now have difficulties in adjusting to "normal" society.

Individuals with disabilities may be considered only a nuisance or "burden" to the family, capable of transforming everyday life in pain and sorrow. Usually the prejudices that disabled mental suffering will be reflected in the family. At times there is a high risk of family breakdown. Man tends to blame his wife for the birth of a child with an abnormality. Usually the mother is placed in the center, as the most required. Next are the father and the social supports that can be mobilized [7-8,10-12].

The birth of the child with an anomaly in the parents cause reactions similar to those caused by severe stress, such as a picture of a child with terminal illness or even the loss of it. Unlike the arrival of a baby expected, there was the birth of another, which is an unknown, unplanned and unknown limitation [4-5]. At this time it is impossible to separate fact from feelings and many actions are contradictory to take account of the life of the parents. Fear, uncertainty, ignorance and prejudice can become in solitude, escape, abandonment, rejection or overprotection $[7,10]$.

The time of diagnosis is extremely delicate and important. The diagnosis sentences a child, changing his status as a person and "stealing", in short, all dream, every hope, every wish it filed by the parents. In view of the family, saying that the child has a disability, it is, a child's "normal" to "abnormal" [7,13].

Identifies some steps in this process that are experienced in different ways by parents and relatives, and the duration and intensity of the same store, usually something to do with the seriousness of the situation. Among these steps is the reaction to the news first shock, followed by the stage of denial, sadness, guilt, anxiety, "shame" and anger [4-5,7,9]. For the authors, the phase represents a stage of denial that can't be accepted; see the child as their own. The father and mother tend to stay alone, carrying a non-sharable pain, since you can't share what is not accepted. Many times, in different ways, avoid "collapse", leaving irritated and angry against everything and everyone. Not infrequently the help of experts is seen as useless. Nothing that the specialist does can change that reality.

Over time, we get the balance and eventually reorganization of life, a period that parents take, or not, your child fully. This moment comes as an insight, a discovery, a simple understanding [4-6]. According to the authors, it is necessary to rebuild from the dreams that his son is. It's no good to insist and want the child to behave the way the parents expect. Many parents say that talking to other parents who have lived or are living the same situation is very positive in the process of understanding and acceptance of having a child with anomalies.

\section{Social Stigma}

Considering that the social environment often classifies people according to their attributes, the individual who has a physical, sensory or mental health tends to be blamed for their "failure to adapt" to society [14]. Those perceived as having socially desirable characteristics are considered normal, while the holders of one or more undesirable attributes are considered deviant $[11,15]$. Every society has a normal pattern, or something considered acceptable within the rules aesthetics, behavior and attitudes, among others. These rules may differ according to gender, purchasing power and even the occupation of the individual [11].

The company still sees a partial view of the disabled, where the predominant part of the whole. The subject is perceived by their difference in the pattern of deficit. It produces an ambiguous social image which, at times, it is seen as weak and fragile, and in others as having the willpower and courage [7-8]. This same society insists on pointing out differences between individuals "normal" and those "outside the normal pattern". Those that don't 
conform to societal norms are considered inferior, different or unusual, which makes many times that through their integration. They are stigmatized [11].

This stigma can be seen as a situation where the individual is disqualified from full social acceptance, your chance of having decreased life [14]. The society can relate to feeling stigmatized by a super-protection or rejection, but never indifference. Somehow, without even realizing it, the community will prevent the disabled from having a development and a life within the normal range adopted by this group [7,14].

Stigmas can be divided into three different groups. At first, some characteristics are related to "visible", whether physical or corporeal. In this group, are present with physical disabilities, amputees and those individuals with Down syndrome. The second group is linked to some trait of personality or behavior, considered derogatory by the community. In this group are those with mental disorders, beggars, alcoholics and homosexuals. The third group consists of the stigmata that are not linked to the individual person, but to race, religion or any other characteristic of the family group to which it belongs [11]. For the authors, the mental disability still carries with it several "brands", including the danger ("all mental illness is dangerous") and disability ("the mental patient is unable to work or study").

\section{Social inclusion}

The term social inclusion is defined as a "citizenship process inherent in all social policies, basic infrastructure (education, health, housing, work, leisure, sports, welfare, transportation)". People build the inclusive process when they realize they can act as instruments of social exclusion, they are able to deconstruct this exclusion (16). The inclusion strengthens the view that is not a disability who has to change, and yes, society. It should provide conditions in which all people are included, thus defining the inclusive society [17].

According Aerts et al., "inclusion is based on the value of human diversity, the right of belonging and the search for solutions to the challenge of the presence of different" [18]. It can be built over a lifetime, and it is a process that never ends, can always be expanded and improved. It reinforced the surprising and gratifying aspect of achievement that represents a person with mental disabilities to enjoy the potential that life gave him and win space in society [19].

Despite the unquestionable progress in legislation that makes the prospect of including the poor, there are few effective achievements in order to change beliefs, eliminating prejudices and change ingrained behaviors in society against people suffering from physical disabilities and / or mental. The change in this framework depends heavily on the work of professionals who provide assistance to the poor. Those responsible for programs of care to people with disabilities can, through acting in society, seeking to dissolve the stigma and discourage discriminatory attitudes.

\section{ASSISTING INDIVIDUALS WITH MENTAL DISABILITIES}

The rights of individuals with disabilities have been recognized in the formation of social movements in favor of minorities, intensified in the after the Second World War [20]. Fortunately, in recent years the defense of a better quality of life and social inclusion of the disabled has been established as a proposal that defies the heavy legacy of care. But the assistance programs targeted to this population need to be careful not to reinforce social stereotypes, merely building a speech focused on illness and symptoms, forgetting the person and "existence-suffering" that is there. The parent and child, their history, their dreams, hopes and expectations, all this is much bigger than the disease [6-8].

In Brazil, Law 7853 was enacted in October 24, 1989, to ensure support for people with disabilities, as well as their social integration. According to Article 1, "general rules are established which ensure the full exercise of individual and social rights of people with disabilities, and their effective social integration, in accordance with this law". As shown in the sole paragraph of Article 2 "... the organs and entities of direct and indirect administration should ... viable, without prejudice to others, the following measures: ... inclusion in the educational system of special education and educational modality covering early education, preschool, the 1st and 2nd degrees, the supplementary, the vocational rehabilitation, with curriculum vitae, steps and requirements for graduation themselves; ... the development of health programs aimed at people with disabilities, developed with the participation of society and that they give rise to the social integration; ... government support to vocational training, vocational guidance, and ensuring access to services concerning, to regular courses including vocational training; ... training and qualification of human resources in various areas of knowledge, including toplevel demand and meet the real needs of people with disabilities, the promotion of research and technological development in all areas of knowledge related to disabled person ..."[21].

In order to regulate the Law 7853 of October 24, 1989, was established in Decree 3298 of December 20, 1999, which provides for the National Policy for the Integration of Persons with Disabilities. According to Article 1 to the National Policy for the Integration of Persons with Disabilities is defined as a "set of normative guidelines aiming at ensuring the full exercise of individual and social rights of people with disabilities" [2].

In this context, the term inclusion has named the initiative to establish rights for the disabled. As stated in Article 6, the National Policy for the Integration of Persons with Disabilities should adopt as guidelines: "to establish mechanisms to accelerate and promote social inclusion of people with disabilities; ... include the disabled person, respected their peculiarities, in all government initiatives related to education, health, work, public building, social security, social assistance, transportation, housing, culture, 
sport and leisure" [2]. However, when considering a few "features facilitators and promoters" of the process of social integration and better living conditions for the poor, the benefits granted by the federal government (monthly benefitmaintenance, scholarship, free pass for public transportation), it remains clear the perpetuation of discrimination against the disabled. The prejudice and stigma against people with disabilities is still very rooted in welfare practices directed at such individuals. To acquire these benefits requires a medical report with the type of disability diagnosed in the applicant, including stating their inability to live independently and to work. This attitude only confirms the persistence of knowledge and practice to protect the poor, historically instituted. It is noticed a paradox between the discourse of social inclusion and what it takes to acquire these benefits granted by the federal government through the Ministry of Social Development and Hunger Alleviation. While social inclusion seeks to mitigate the difference, these welfare programs tend to emphasize it, reinforcing the stigma of disability.

\section{The participation of Non-Governmental Organizations}

Speaking in favor of inclusion of different (deficient) became stronger through Non-Governmental Organizations. These organizations take the discourse of difference to the social environment and overturn the hegemony of a false equality which ends up being exclusionary. According to Cavalcante, the similarity between the names of various associations of support and assistance to people with disabilities highlights certain social identity established by this set of associations, often formed by parents. These organizations are formed around a common goal, which is identified by a desire to build services that meet the special needs of their children [3].

The multiplication of Non-Governmental Organizations in the world expresses the inability of the current democratic system perform various actions desired by citizens. The Non-Governmental Organizations have been present for centuries, also referred to as "unions", "associations" and "societies" [22]. The term "Non Governmental Organization", more modern, has a political idea that other denominations do not necessarily possess. Among the characteristics of Non Governmental Organizations highlights the fact they have no profit. Furthermore, although non-partisan political organizations and non-governmental organizations, sometimes maintain cooperative relationship with governments [23].

Several associations aimed at assisting the individual with mental retardation were created in Brazil since the beginning of the century. Among them one can cite the Pestalozzi Society, founded in 1932. In a particular way, this institution was able to print a pedagogical model of specialized care to individuals with mental deficiency [24-25]. According to the authors, in Brazil, assistance to people with learning disabilities is a service performed, mostly by institutions such as Pestalozzi and the Association of Parents and Friends of Exceptional Children, who survive amidst the background of widespread disaffection government.

The practice carried out in the field of special education before 90 years was guided in the "medical model of disability", which highlighted the disease or the inability to be rehabilitated. As a result, institutions have specialized in serving the people by types of disabilities in special schools, rehabilitation centers, sheltered workshops, special clubs and sports associations. They began to pursue the ideal of standardization for greater social integration, as opposed to social exclusion, the ideology that considered totally disabled and unable useless [3].

From 90 years, gained momentum a "social model of disability". In this model of society is called to reflect on how to create problems and reinforces the disadvantage when they maintain restrictive environments, goods and objects inaccessible physical point of view, policies and practices and misinformation about the rights of this social group [3]. When looking for schooling for the disabled realizes that your success is the respect for difference, considering the equality. As you are treated as equals, with rights and duties, rewards and reprimands, there are better results. These citizens, therefore, surprise us every day, with its potential new heights [5].

With increased publicity and media attention, coupled with the struggle of many professionals, the family stopped to "hide" the person who needs special care, and some professionals have stopped "hide" them.

\section{DISCUSSION}

Dealing with people marked by disability is a complex task $[6,8,26]$. The professional who is dedicated to people with disabilities and / or their families should be aware of the difficulties faced by some families who have a relative diagnosed with any mental impairment $[7,11,26]$.

The heterogeneity of health needs and care practices of the person with mental disabilities demand different responses by the services. Many professionals involved in these practices still focus on a routine consultation and guidance traditional preventive program. According Gil, it is not uncommon to see in daily practice, the profile of certain professionals is not ideal to work from the perspective of comprehensive health care and practices that encompass the promotion, protection, prevention, care early healing and rehabilitation [27].

Health professionals must be aware that you are allowed to interact with the patient during treatment. The caregiver must remember that each individual is unique, even in some cases, the type of tasks performed do not vary much between the assisted populations. This understanding can foster the relationship for both parties, giving the patient a more humane and better performance to the professional $[11,26]$. The new curriculum guidelines stress the need to plan the work of care taking into account specific local, regional and cultural. The very perception of health care influences 
their performance that often is far from the reality facing the people he assisted [18].

Professionals should be aware of the need for parents to understand and realize their real needs and the care of his son. The family is always prepared to provide relevant information about the mentally handicapped, as well as on their previous experiences [26]. Several families, however, complain that certain professionals are indifferent in the care of his son, not even respect as a human being [10]. The individual must be perceived from a global view (in which predominates the whole of the part), the complexity of problems faced in day-to-day and richness of expression can have. Certain practices of health and education, however, still "pinking" the individual at his level of "defects". They tend to identify the "poor", his disability and his family as pathology $[3,26]$.

The health professional should, in their daily practice, tackle the stigma of the mentally disabled and ensure their full involvement in the community. However, in many cases the trader does not feel safe and ends up reproducing the prejudice to these people, dealing overprotective (infantilizing the individual) or rude (hiding the fear that he feel) $[7,11]$. To avoid this situation, the caregiver must never forget the importance of acting on the basis of scientific evidence on the one hand, and based on the ability to discern ethical and social sensitivity on the other.

The view of the family on the development of children with disabilities is often contrary to the conclusions of the doctors and society in general. There is an administration of the internal voltage mixed feelings as love the child as it is, its borders, or ignore his disability, dropping to seek rehabilitative care $[3-4,7,10,26,28]$.

The recurrence of seizures of children, the need for general hospitals and to face the hostile circumstances in which this can happen many parents try to do everything to be self-sufficient in handling various situations. The fear of not being able to enlist the help of hospitals and the coldness and lack of information professionals, exposure of the child's, lay dying in a crisis, all this means that parents are required beyond what seems reasonable. The difficulty of dealing with a special child is experienced at times as deep impotence, may be confused with dislike [7].

Often the person with mental disabilities, as well as their family goes through several treatments, a pilgrimage in search of rescuing a "lost health" as a result of a disability or disorder. This relentless pursuit of health may be associated with feelings of frustration, helplessness and insecurity. The family tends to seek support, supporting the bias and weight, and while passing through various abuses, do not quit, insists, resisting, questioning the "no" until you find that the social doors and receive your child.

Many families are struggling to learn all you can about the disability. This time looking for a way, a guide, a friend, a "brother" to facilitate, at the right time, the search for information that generates the knowledge essential to treatment. It is not uncommon for parents to be the great builders of care improvement in the disability of his son $[6,26]$. When he realizes that something is wrong with their child, the mother begins a true way of the cross in going to doctors.

When working with patients with disabilities, it is important to have a differentiated consideration in relation to parents, which can be great allies during treatment. The owner must demonstrate ability to communicate, making parents realize their kids are under the care of a person interested in the welfare of the patient. Only then will feel safe. The project team must be aware of this issue, since the parents may have already gone through several professionals who were unable to cope with their children and therefore their attitude towards the situation is extreme distrust [7, 26]. It is often informally, in conversations with the patient or his family, are collected important information related to the case by a health professional $[6,8,11]$.

The health team that works in the process of social integration and rehabilitation of people with intellectual disabilities needs to be attentive and sensitive with the family stories. It's necessary for determine the shape and scope of work. No use professional "to place" with an attitude that is not receptive to the family. To achieve positive results, the family needs to identify with the professional care of a child.

The preconception is still large and in some cases, even revulsion against people with mental disabilities. The professional often "inherits" from society those negative feelings against the mentally disabled. If you are not aware of this fact, just going through these feelings for the person with disabilities and their families, to realize this approach, lacks confidence that professional face and often, just abandon the treatment. The family is frustrated and even angry face the prejudice of their own professional involved.

\section{CONCLUSION}

The way society perceives and relates to people with disabilities is a repetition of the speech and behavior of its own professionals and programs involved in social integration and rehabilitation of these individuals. To minimize this situation, the educational institutions of human resources, and assistance programs aimed at the disabled, need to promote reflections on the densest kind of discourse and practices used in everyday life of these people and their families. They should not act based on prejudice.

The disability is a challenge for all who wish to accept, understand and help people with differences. We need a better understanding of the limits of the disabled, a targeted support for its development and, above all, their value and credibility to the personal and societal importance. The bias is still very present in everyday life and assumes a different guise in every situation, always emphasizing the difference of the individual. The value of the disabled person is questioned by what you can do and the way he does.

Although individuals with intellectual disability require special attention, the deficiency can't be identified as synonymous of disability in all aspects of life. It is important that professionals highlighted positive aspects of 
individuals with mental disabilities, and do not bind only to its limitations.

The struggle for citizenship and protection of disabled people plays an important role in building a more humane society, ethics and solidarity. It means moving toward the end of social prejudice.

\section{REFERENCES}

1. Telford CW, Sawrey JM. O indivíduo excepcional. $5^{\text {th }}$ ed. Rio de Janeiro: Guanabara Koogan. 1988. 153p.

2. Brasil. Decreto no 3.298 de 20/12/1999. Available at: <http://www cedipod.org.br/dec3298.htm>. Accessed: February 27, 2012.

3. Cavalcante F. Pessoas Muito Especiais: a construção social do portador de deficiência e a reinvenção da família. Rio de Janeiro: FIOCRUZ; 2003. $213 \mathrm{p}$.

4. Ahmann E. Review and commentary: two studies regarding giving "bad news". Pediatr Nurs 1998;24:554-6.

5. Aguiar MJ. Cidadania e deficiência. In: Salgado MI, Valadares ER (Org). Para compreender a deficiência. Belo Horizonte: Rona; 2000. p. 271-7

6. Cardoso MH. Uma produção de significados sobre a síndrome de Down. Cad Saude Publica 2003;19:101-9. https://doi.org/10.1590/S0102$311 \times 2003000100011$

7. Silva NL, Dessen MA. Crianças com Síndrome de Down e suas interações familiares. Psicol Reflex Crit 2003;16:503-14. https://doi.org/10.1590/ S0102-79722003000300009

8. Harvey B. Down's syndrome: a biopsychosocial perspective. Nurs Stand 2004;18:43-5. https://doi.org/10.7748/ns2004.04.18.30.43.c3587

9. Guerra FA, Llerena Jr JC, Gama SG, Cunha CB, Theme Filha MM. Defeitos congênitos no Município do Rio de Janeiro, Brasil: uma avaliação através do SINASC (2000-2004). Cad Saude Publica 2008;24:140-9. https://doi. org/10.1590/S0102-311X2008000100014

10. Larson E. Reframing the meaning of disability to families: the embrace of paradox. Soc Sci Med 1998;47:865-75. https://doi.org/10.1016/S02779536(98)00113-0

11. Jorge MA, Alencar OS, Belmonte PR, Reis VL. O indivíduo e o seu contexto social. In: (Orgs.). Escola Politécnica de Saúde Joaquim Venâncio. Textos de Apoio em Saúde Mental. Rio de Janeiro: Fiocruz. 2003. p. 51-71.

12. Minayo MC. É possível haver vida onde só parece haver perturbação? In: Cavalcante FG. Pessoas muito especiais: a construção social do portador de deficiência e a reinvenção da família. Rio de Janeiro: Fiocruz; 2003. p. 09-13.
13. Cavalcante F. Família, subjetividade e linguagem: gramáticas da criança "anormal". Ciênc Saúde Coletiva 2001;6:125-37. https://doi.org/10.1590/ S1413-81232001000100011

14. Goffman E. Stigma: notes on the management of spoiled identity. $5^{\text {th }}$ ed. London: Pelican Books; 2004. 314 p.

15. Coelho MT, Almeida Filho N. Conceitos de saúde em discursos contemporâneos de referência científica. Hist Cienc Saúde-Manguinhos 2002;9:315-33. https://doi.org/10.1590/S0104-59702002000200005

16. Pinto MD. Desafios na educação inclusiva. In: Salgado MI, Valadares ER. (Orgs). Para compreender a deficiência. Belo Horizonte: Rona; 2000. p. 233-7.

17. Monteiro SM. A inclusão. In: Salgado MI, Valadares ER (Orgs). Para compreender a deficiência. Belo Horizonte: Rona; 2000. p. 232-3.

18. Aerts D, Alves GG, La Salvia MW, Abegg C. Promoção de saúde: a convergência entre as propostas da vigilância da saúde e da escola cidadã. Cad Saude Publica 2004;20:1020-8. https://doi.org/10.1590/ S0102-311X2004000400017

19. Voivodic MA. Inclusão escolar de crianças com síndrome de Down. Petrópolis: Vozes; 2003. 87p.

20. Brumer A, Pavei K, Mocelin D. Saindo da "escuridão": perspectivas da inclusão social, econômica, cultural e política dos portadores de deficiência visual em Porto Alegre. Sociologias 2004;6:300-27. https:// doi.org/10.1590/s1517-45222004000100013

21. Brasil. Lei $n^{\circ} 7.853$, de 24/10/1989. Available at: <http://www.pge.sp.gov $\mathrm{br} /$ centrodeestudos/bibliotecavirtual/dh/volume\%20i/deflei7853.htm> Accessed October 22, 2012.

22. Kalk A. A cooperação entre uma ONG e os Estados "anfitriões" no controle da hanseníase na América Latina. Cad Saude Publica 2003; 19:663-6. https://doi.org/10.1590/S0102-311X2003000200033

23. Ramos S. O papel das ONGs na construção de políticas de saúde: Aids, a saúde da mulher e a saúde mental. Ciênc Saúde Coletiva 2004; 9:1067-78. https://doi.org/10.1590/S1413-81232004000400027

24. Xavier MA. Diálogo com a esperança. São Paulo: Memmon Edições Científicas. 1999. 59p

25. Assumpção Jr FB, Sprovieri MH. Introdução ao estudo da deficiência mental. São Paulo: Memmon Edições Científicas; 2000. 126p.

26. Oliveira AC, Pordeus IA, Luz CL, Paiva SM. Mothers' perceptions concerning oral health of children and adolescents with Down syndrome: a qualitative approach. Eur J Paediatr Dent 2010;11:27-30.

27. Gil CR. Formação de recursos humanos em saúde da família: paradoxos e perspectivas. Cad Saude Publica 2005;21:490-8. https://doi.org/10.1590/ S0102-311X2005000200015

28. Grossi R. A família da pessoa portadora de deficiência mental. Pediatr Mod 1999;35:840-6 